TITLE:

\title{
Mechanism of Electrolytic Reduction of SiO at Liquid Zn Cathode in Molten $\mathrm{CaCl}$
}

$\operatorname{AUTHOR}(\mathrm{S}):$

Ma, Yuanjia; Ido, Akifumi; Yasuda, Kouji; Hagiwara, Rika; Homma, Takayuki; Nohira, Toshiyuki

\section{CITATION:}

Ma, Yuanjia ... [et al]. Mechanism of Electrolytic Reduction of SiO at Liquid Zn Cathode in Molten CaCl. Journal of The Electrochemical Society 2019, 166(6): D162-D167

ISSUE DATE:

2019-03-13

URL:

http://hdl.handle.net/2433/245274

\section{RIGHT:}

(c) The Electrochemical Society, Inc. 2019. All rights reserved. Except as provided under U.S. copyright law, this work may not be reproduced, resold, distributed, or modified without the express permission of The Electrochemical Society (ECS). The archival version of this work was published in J. Electrochem. Soc. 2019 volume 166, issue 6, D162-D167; この 論文は出版社版でありません。引用の際には出版社版をご確認ご利用ください。; This is not the published version.

Please cite only the published version. 
2 Title

3 Mechanism of Electrolytic Reduction of $\mathrm{SiO}_{2}$ at Liquid $\mathrm{Zn}$ Cathode in Molten $\mathrm{CaCl}_{2}$

4

\section{Authors}

6 Yuanjia Ma ${ }^{1}$, Akifumi $\mathrm{Ido}^{2}, \mathrm{Kouji}_{\text {Yasuda }}{ }^{2,3, *}$, Rika Hagiwara ${ }^{2, *}$, Takayuki Homma ${ }^{4, *}$,

7 Toshiyuki Nohira ${ }^{1, *, Z}$

8

\section{$9 \quad$ Affiliations}

$10{ }^{1}$ Institute of Advanced Energy, Kyoto University, Gokasho, Uji, Kyoto 611-0011, Japan

$11{ }^{2}$ Graduate School of Energy Science, Kyoto University, Yoshida-honmachi, Sakyo-ku,

12 Kyoto 606-8501, Japan

$13{ }^{3}$ Agency for Health, Safety and Environment, Yoshida-honmachi, Sakyo-ku, Kyoto

14 606-8501, Japan

$15{ }^{4}$ Faculty of Science and Engineering, Waseda University, 3-4-1 Okubo, Shinjuku-ku,

16 Tokyo 169-8555, Japan

17 *Electrochemical Society Active Member.

$18 \quad{ }^{\mathrm{Z}}$ Corresponding author: nohira.toshiyuki.8r@kyoto-u.ac.jp 


\section{Abstract}

in molten $\mathrm{CaCl}_{2}$ was investigated with the aim of establishing a new production process of solar-grade $\mathrm{Si}$. Three types of $\mathrm{Zn} / \mathrm{SiO}_{2}$ contacting electrodes were prepared depending on the objectives. Cyclic voltammetry suggested two reduction mechanisms of $\mathrm{SiO}_{2}$ at a $\mathrm{Zn}$ electrode. One is a direct electrolytic reduction that proceeds at potentials more negative than $1.55 \mathrm{~V}$ vs. $\mathrm{Ca}^{2+} / \mathrm{Ca}$. The other is an indirect reduction by liquid $\mathrm{Ca}-\mathrm{Zn}$ alloy at potentials more negative than $0.85 \mathrm{~V}$. The both reduction mechanisms were confirmed to proceed at $0.60 \mathrm{~V}$ by electrolysis and immersion experiments. Impurity analysis by ICP-AES was conducted for the Si prepared by potentiostatic electrolysis at $0.60 \mathrm{~V}$, and confirmed that the concentrations of the metal elements and $\mathrm{P}$ were lower than the target levels for primary Si before directional solidification process.

\section{Introduction}


37 PV cells has experienced a rapid growth in the last decade. Accordingly, their production volume increased in the 21 st century by a factor of approximately 250 i.e.,

39 from $0.285 \mathrm{GW}$ in 2000 to $75.5 \mathrm{GW}$ in 2016 . Among the many types of solar cells,

40 crystalline Si solar cells accounted for $94.3 \%$ of the worldwide production in $2016^{1}$. The

41 global production of high-purity crystalline Si also increased to 412,600 tons in 2016

42 i.e., by a factor of approximately 18 over the level achieved in $2000^{2}$. Therefore, crystalline Si solar cells would most likely remain the main product of the PV industry in the long term.

The high-purity Si used in crystalline $\mathrm{Si}$ solar cells is known as solar-grade $\mathrm{Si}$ (SOG-Si), and requires a purity of 6-7N. Approximately $90 \%$ of SOG-Si is currently

47 produced by the Siemens process ${ }^{3-5}$. To develop a next-generation production process

48 for $\mathrm{SOG}-\mathrm{Si}$, purification of metallurgical-grade $\mathrm{Si}^{6-11}$ and metallothermic reduction of

49 silicon halides by metal reductants ${ }^{12-15}$ were investigated. One of the metallothermic

50 reduction processes proposed is a reduction of $\mathrm{SiCl}_{4}$ by $\mathrm{Zn}$, and is known as the Du Pont

51 process, which was the commercial process for high-purity Si production before the

52 Siemens process was introduced ${ }^{12}$. There are two major advantages of the Du Pont process. One is no formation of $\mathrm{Si}-\mathrm{Zn}$ intermetallic compounds due to the low chemical

54 affinity of $\mathrm{Zn}$ with $\mathrm{Si}^{16}$. The other is the easy removal of the unreacted $\mathrm{Zn}$ and $\mathrm{ZnCl}_{2}$ 
generated from the Si product because of their high vapor pressures.

For the past two decades, we have been studying the direct electrolytic reduction of solid $\mathrm{SiO}_{2}$ to $\mathrm{Si}$ in molten $\mathrm{CaCl}_{2}$ as a new production process of SOG-Si ${ }^{17-}$ ${ }^{20}$. Here, since purification of $\mathrm{SiO}_{2}$ up to $6-7 \mathrm{~N}$ is possible at low $\operatorname{cost}^{21,22}$, such purified $\mathrm{SiO}_{2}$ is assumed to be used as the raw material ${ }^{22}$. In this process, electrochemical reduction of insulating $\mathrm{SiO}_{2}$ is realized by using a $\mathrm{SiO}_{2}$ contacting electrode, which provides the three-phase zone of conductor/ $/ \mathrm{SiO}_{2} / \mathrm{CaCl}_{2}{ }^{17}$.

$$
\mathrm{SiO}_{2}(s)+4 \mathrm{e}^{-} \rightarrow \mathrm{Si}(s)+2 \mathrm{O}^{2-}
$$

62 Several other research groups have also investigated the direct electrolytic reduction of

$63 \mathrm{SiO}_{2}{ }^{23-34}$. One of the challenges faced in the industrial application of this process is the efficient recovery and separation of the powdery $\mathrm{Si}$ product from unreacted $\mathrm{SiO}_{2}$ and molten $\mathrm{CaCl}_{2}{ }^{35}$. Recently, we proposed an electrolytic reduction process of $\mathrm{SiO}_{2}$ using a liquid $\mathrm{Zn}$ cathode in molten $\mathrm{CaCl}_{2}$. Since the electrolysis product is liquid $\mathrm{Si}-\mathrm{Zn}$ alloy, its separation from unreacted $\mathrm{SiO}_{2}$ and molten salt is expected to be easier than that entailed in the use of the conventional solid cathode ${ }^{36,37}$. The choice of $\mathrm{Zn}$ as an alloying element stems from the very factors that render the Du Pont process advantageous, i.e., the use of $\mathrm{Zn}$ ensures the formation of no intermetallic compounds 
with $\mathrm{Si}$, and facilitates easy removal of both $\mathrm{Zn}$ and $\mathrm{ZnCl}_{2}$. Here, the most important point is that the existence of molten salt over liquid $\mathrm{Zn}$ effectively suppresses the evaporation of $\mathrm{Zn}$ even at high temperatures such as $1123 \mathrm{~K}$. Figure 1 schematically illustrates the proposed process ${ }^{36,37}$. The overall process consists of three major steps: electrolysis, precipitation, and refining. In the electrolysis step, solid $\mathrm{SiO}_{2}$ is reduced to form liquid Si-Zn alloy at a liquid $\mathrm{Zn}$ cathode.

$$
\begin{aligned}
\mathrm{SiO}_{2}(s)+\mathrm{Si}-\mathrm{Zn} & (l, \text { low } \mathrm{Si} \text { conc. })+4 \mathrm{e}^{-} \\
& \rightarrow \mathrm{Si}-\mathrm{Zn}(l, \text { high } \mathrm{Si} \text { conc. })+2 \mathrm{O}^{2-}
\end{aligned}
$$

In the precipitation step, solid $\mathrm{Si}$ is recovered by lowering the temperature of the liquid $\mathrm{Si}-\mathrm{Zn}$ alloy.

$$
\mathrm{Si}-\mathrm{Zn}(l, \text { high Si conc. }) \rightarrow \mathrm{Si}(s)+\mathrm{Si}-\mathrm{Zn}(l, \text { low Si conc. })
$$

80 Since the solubility of $\mathrm{Si}$ in liquid $\mathrm{Zn}$ is 6 at.\% at $1123 \mathrm{~K}$ and 1 at.\% at $923 \mathrm{~K}^{38}, 5$ at.\% of solid $\mathrm{Si}$ with reference to $\mathrm{Zn}$ is theoretically recovered when the temperature is lowered from $1123 \mathrm{~K}$ to $923 \mathrm{~K}$. After the precipitation step, the Si-Zn alloy with a low concentration of $\mathrm{Si}$ is reused as the cathode in the electrolysis step. The $\mathrm{Si}$ recovered is then subjected to the refining step: that entails vacuum refining to remove residual $\mathrm{Zn}$ and directional solidification to manufacture SOG-Si ingots. 
87 with molten $\mathrm{CaCl}_{2}$ was confirmed at $1123 \mathrm{~K}^{36,37}$. Moreover, the alloying rate between

solid $\mathrm{Si}$ and liquid $\mathrm{Zn}$ was measured, and the formation of liquid $\mathrm{Si}-\mathrm{Zn}$ alloy at a liquid

$89 \mathrm{Zn}$ cathode was demonstrated ${ }^{36,37}$. After potentiostatic electrolysis at $0.9 \mathrm{~V}$, Si particles

90 of sizes in the range $2-30 \mu \mathrm{m}$ were precipitated in the solidified $\mathrm{Zn}$ matrix. The

91 formation of liquid $\mathrm{Ca}-\mathrm{Zn}$ alloy (reaction [4]) was also suggested by cyclic

92 voltammetry.

$$
\mathrm{Zn}(l)+\mathrm{Ca}^{2+}+2 \mathrm{e}^{-} \rightarrow \mathrm{Ca}-\mathrm{Zn}(l)
$$

Based on these results, the electrolytic reduction of $\mathrm{SiO}_{2}$ at a liquid $\mathrm{Zn}$ cathode was considered to be a mixed mechanism of (A) direct electrolytic reduction of $\mathrm{SiO}_{2}$ (reaction [5]), and (B) indirect reduction of $\mathrm{SiO}_{2}$ by liquid $\mathrm{Ca}-\mathrm{Zn}$ alloy (reaction [6]).

$$
\begin{aligned}
& \mathrm{SiO}_{2}(s)+\mathrm{Zn}(l)+4 \mathrm{e}^{-} \rightarrow \mathrm{Si}-\mathrm{Zn}(l)+2 \mathrm{O}^{2-} \\
& \mathrm{SiO}_{2}(s)+\mathrm{Ca}-\mathrm{Zn}(l) \rightarrow \mathrm{Si}-\mathrm{Zn}(l)+2 \mathrm{CaO}(l)
\end{aligned}
$$

96 However, the evidence of (B) i.e., indirect reduction was not seen, and the contributions of (A) and (B) were not investigated. In the present study, a series of electrolysis and immersion experiments were

99 conducted to confirm the indirect reduction of $\mathrm{SiO}_{2}$. Based on the results, the mixed reduction mechanism was discussed in terms of reduction rate. Finally, impurity analysis was performed for the Si particles produced at the $\mathrm{Zn}$ cathode. 


\section{Experimental}

All experiments were performed in a dry $\mathrm{Ar}$ atmosphere at $1123 \mathrm{~K} . \mathrm{An}^{\mathrm{Ag}}+\mathrm{Ag}$

electrode was used as the reference electrode in the experiments. The experimental

conditions for (a) cyclic voltammetry, (b) electrolytic reduction of $\mathrm{SiO}_{2}$ plates, and (c)

electrolytic reduction of $\mathrm{SiO}_{2}$ particles are described below.

(a) Cyclic Voltammetry

110

Figure 2 shows a schematic illustration of the electrolysis cell for the observation of the reduction behavior of $\mathrm{SiO}_{2}$ at a liquid $\mathrm{Zn}$ cathode. Figure 3(a)

112 schematically illustrates the structure of the liquid $\mathrm{Zn}$ working electrode for cyclic

113 voltammetry. Approximately $70 \mathrm{~g}$ of Zn (Wako Pure Chemical Corp., reagent grade,

114 granule) was charged into a small $\mathrm{Al}_{2} \mathrm{O}_{3}$ crucible (AS ONE, o.d. $45 \mathrm{~mm} \times$ height $36 \mathrm{~mm}$,

$115>99 \%$ ). The small $\mathrm{Al}_{2} \mathrm{O}_{3}$ crucible was placed at the bottom of another $\mathrm{Al}_{2} \mathrm{O}_{3}$ crucible

116 (AS ONE, o.d. $90 \mathrm{~mm} \times$ i.d. $80 \mathrm{~mm} \times$ height $140 \mathrm{~mm},>99 \%$ ), and approximately $500 \mathrm{~g}$

117 of $\mathrm{CaCl}_{2}$ (Kojundo Chemical Laboratory Co., Ltd., >99\%) was charged. A W wire (The

Nilaco Corporation, diameter $2.0 \mathrm{~mm}, 99.95 \%$ ) threaded into an $\mathrm{Al}_{2} \mathrm{O}_{3}$ tube (Nikkato

119 Corp., SSA-S grade, o.d. $6.0 \mathrm{~mm} \times$ i.d. $4.0 \mathrm{~mm}$ ) or a $\mathrm{SiO}_{2}$ tube (Soei Riken Corp., o.d. 
$1206.0 \mathrm{~mm} \times$ i.d. $2.0 \mathrm{~mm}$ ) was used as the current lead and immersed in the liquid $\mathrm{Zn}$ in the

121 small $\mathrm{Al}_{2} \mathrm{O}_{3}$ crucible. The direct electrolytic reduction of $\mathrm{SiO}_{2}$ occurs at the three-phase

122 interface of $\left(\mathrm{Al}_{2} \mathrm{O}_{3}\right.$ or $\left.\mathrm{SiO}_{2}\right) / \mathrm{CaCl}_{2}$ (1)/Zn (1), as shown in Fig. 3(a). For comparison, a square-shaped plate of single-crystal Si (ca. $30 \mathrm{~mm} \times 5 \mathrm{~mm} \times 0.5 \mathrm{~mm}$, p-type, (100), $1.5-3.0 \times 10^{-3} \Omega \mathrm{cm}$ at $298 \mathrm{~K}$ ) was also used as the working electrode. The counter electrode was a square graphite bar (Toyo Tanso Co., Ltd., $5 \mathrm{~mm} \times 5 \mathrm{~mm} \times$ height 50 $\mathrm{mm})$.

(b) Electrolytic reduction of $\mathrm{SiO}_{2}$ plates

Figure 3(b) shows a schematic illustration of the liquid $\mathrm{Zn}$ cathode for the investigation of the effect of indirect reduction of $\mathrm{SiO}_{2}$ by liquid $\mathrm{Ca}-\mathrm{Zn}$ alloy. Approximately $125 \mathrm{~g}$ of $\mathrm{Zn}$ was charged into a small $\mathrm{ZrO}_{2}$ crucible (AS ONE, $\mathrm{ZrO}_{2}$ 91.5\%, $\mathrm{Y}_{2} \mathrm{O}_{3} 8 \%$, o.d. $60 \mathrm{~mm} \times$ i.d. $52 \mathrm{~mm} \times$ height $35 \mathrm{~mm}$ ). The $\mathrm{ZrO}_{2}$ crucible was placed in a graphite crucible (Toyo Tanso Co., Ltd., IG-110 grade, o.d. $100 \mathrm{~mm} \times$ i.d. 90 $\mathrm{mm} \times$ height $120 \mathrm{~mm}$ ) to which a graphite rod (Toyo Tanso Co., Ltd., IG-110 grade, diameter $9 \mathrm{~mm}$ ) was fixed using a stainless steel screw. Approximately $500 \mathrm{~g} \mathrm{of} \mathrm{CaCl}_{2}$ was charged into the graphite crucible. $\mathrm{A} \mathrm{SiO}_{2}$ plate (Soei Riken Corp., $25 \mathrm{~mm} \times 10 \mathrm{~mm}$ $\times$ thickness $1 \mathrm{~mm}$ ), fixed to an insulating tube of $\mathrm{Al}_{2} \mathrm{O}_{3}$ (Nikkato Corp., SSA-S grade, 
o.d. $2.5 \mathrm{~mm} \times$ i.d. $1.5 \mathrm{~mm}$ ) by winding a Mo wire (The Nilaco Corporation, diameter $0.20 \mathrm{~mm}, 99.95 \%$ ), was immersed into the liquid $\mathrm{Zn}$ in the small $\mathrm{ZrO}_{2}$ crucible. The counter electrode was the graphite crucible, and the graphite rod was used as the current lead. The test piece prepared by electrolysis or immersion of $\mathrm{SiO}_{2}$ plate was washed with distilled water to remove the salt, and then immersed in $\mathrm{HCl}$ aq. ( 3 wt.\%, prepared from Fujifilm Wako Pure Chemical Corporation, reagent grade, 36 wt.\%) overnight to dissolve the $\mathrm{Zn}$ metal on the surface of the plate. An optical microscope (Thanko Inc., DILITE30) was used for surface observation, and the masses of the $\mathrm{SiO}_{2}$ plates were measured before and after the experiment.
(c) Electrolytic reduction of $\mathrm{SiO}_{2}$ particles

Figure 4 schematically illustrates a cell for the electrolytic reduction of $\mathrm{SiO}_{2}$ particles. A total of $335 \mathrm{~g}$ of $\mathrm{Zn}$ and $349 \mathrm{~g}$ of $\mathrm{CaCl}_{2}$ were charged into an $\mathrm{Al}_{2} \mathrm{O}_{3}$ crucible. After the temperature was raised to $1123 \mathrm{~K}$, a total of $16.2 \mathrm{~g}$ of $\mathrm{SiO}_{2}$ particles (Kojundo Chemical Laboratory Co., Ltd., 0.25-1.00 mm, 99.995\%) was charged into molten salt uniformly using a quartz funnel. The $\mathrm{SiO}_{2}$ particles floated on the surface of liquid $\mathrm{Zn}$ in molten $\mathrm{CaCl}_{2}$ because the densities of liquid $\mathrm{CaCl}_{2}$, solid $\mathrm{SiO}_{2}$, and liquid $\mathrm{Zn}$ are $2.05 \mathrm{~g}$ $\mathrm{cm}^{-3}, 2.2 \mathrm{~g} \mathrm{~cm}^{-3}$, and $5.9 \mathrm{~g} \mathrm{~cm}^{-3}$, respectively, at $1123 \mathrm{~K}$. A W wire (The Nilaco 
156 Corporation, diameter $1.0 \mathrm{~mm}, 99.95 \%$ ) threaded into an alumina tube was used as the

157 current lead for liquid Zn. The counter electrode was a graphite rod (Toyo Tanso Co.,

158 Ltd., IG-110 grade, diameter $20 \mathrm{~mm} \times$ height $40 \mathrm{~mm}$ ) fixed to a thinner graphite rod

159 (Toyo Tanso Co., Ltd., IG-110 grade, diameter $9 \mathrm{~mm} \times$ height $500 \mathrm{~mm}$ ). The sample

160 obtained after electrolysis was cooled from $1123 \mathrm{~K}$ to $773 \mathrm{~K}$ for $35 \mathrm{~h}$, then maintained

161 at $773 \mathrm{~K}$ for $10 \mathrm{~h}$, and further cooled to $298 \mathrm{~K}$ for $5 \mathrm{~h}$. The ingot of $\mathrm{Zn}$ metal was

162 recovered after the removal of $\mathrm{CaCl}_{2}$ by flowing water. The $\mathrm{Zn}$ metal ingot was

163 dissolved in $\mathrm{HCl}$ aq. (20 wt.\%). The particles recovered after the dissolution of $\mathrm{HCl}$

164 were further washed; they were alternately immersed in $\mathrm{HCl}$ aq. (10 wt.\%) twice and in

165 HF aq. (5 wt.\%, prepared from Tama Chemicals Co., Ltd., AA-100 grade, 38 wt.\%)

166 once overnight. The analysis was conducted using X-ray diffraction (XRD, Rigaku,

167 Ultima $4, \mathrm{Cu}-\mathrm{K \alpha}, \lambda=1.5418 \AA, 40 \mathrm{kV}, 40 \mathrm{~mA}$ ) and inductively coupled plasma atomic emission spectroscopy (ICP-AES; AMETEK, Inc., SPECTROBLUE).

\section{Result and Discussion}

(a) Cyclic Voltammetry

Figure 5 shows the cyclic voltammograms at the liquid $\mathrm{Zn}$ (black color) and $\mathrm{Si}$ 
peaks at around $1.3-1.4 \mathrm{~V}$ vs. $\mathrm{Ca}^{2+} / \mathrm{Ca}$ correspond to the reduction of surface $\mathrm{SiO}_{2}$ film to metallic $\mathrm{Si}$ and the oxidation of $\mathrm{Si}$ into $\mathrm{SiO}_{2}$ layer, respectively ${ }^{35,39}$. The smaller anodic current compared with the cathodic current is due to the passivation effect of the formed $\mathrm{SiO}_{2}$ layer. The redox at $0.5 \mathrm{~V}$ is attributed to $\mathrm{CaSi}_{2} / \mathrm{Si}^{35,}{ }^{39}$. The solid and broken black lines show the voltammograms at $\mathrm{Zn}$ electrodes using $\mathrm{Al}_{2} \mathrm{O}_{3}$ and $\mathrm{SiO}_{2}$ tubes, respectively. A sharp increase in cathodic current at $0.85 \mathrm{~V}$ is seen at both the $\mathrm{Zn}$ electrodes. Since the electrochemical reduction of $\mathrm{Al}_{2} \mathrm{O}_{3}$ does not occur in the potential range measured ${ }^{40}$, the cathodic current is attributed to the formation of liquid $\mathrm{Ca}-\mathrm{Zn}$ alloy, which was already confirmed by potentiostatic electrolysis at potentials more negative than $0.85 \mathrm{~V}^{37}$. In the case of the $\mathrm{Zn}$ electrode with $\mathrm{SiO}_{2}$, the rest potential is $1.55 \mathrm{~V}$, which is more positive than that of the Si plate electrode $(1.47 \mathrm{~V})$, and the cathodic current is observed from the rest potential in the negative scan even at potentials more positive than $1.3 \mathrm{~V}$. These results suggest the formation of liquid $\mathrm{Si}-\mathrm{Zn}$ alloy with Si activity lower than unity with respect to pure solid Si. The cathodic current at the $\mathrm{Zn}$ electrode with $\mathrm{SiO}_{2}$ was $80 \mathrm{~mA}$ larger than that with $\mathrm{Al}_{2} \mathrm{O}_{3}$, which also suggests electrolytic reduction of $\mathrm{SiO}_{2}$ (reaction [5]). 
conducted at $0.60 \mathrm{~V}$ and then at $0.90 \mathrm{~V}$. Specifically, the experiments were conducted in the following order: [A1] electrolysis at $0.90 \mathrm{~V}$ for $30 \mathrm{~min}$, [B1] immersion for $30 \mathrm{~min}$, [A2] electrolysis at $0.60 \mathrm{~V}$ for $30 \mathrm{~min}$, and [B2] immersion for $30 \mathrm{~min}$. Here, a new $\mathrm{SiO}_{2}$ plate was used in each step. As a result, four samples, A1, B1, A2 and B2, were prepared. Since electrolysis was not conducted for the samples B1 and B2, the reduction of $\mathrm{SiO}_{2}$ could be advanced only due to indirect reduction by liquid $\mathrm{Ca}-\mathrm{Zn}$ alloy (reaction [6]). On the other hand, the reduction of the samples A1 and A2 could proceed by a mixed reduction mechanism comprising direct electrolytic reaction (reaction [5]) and indirect reduction by liquid $\mathrm{Ca}-\mathrm{Zn}$ alloy. The optical images of the samples A1, B1, A2, and B2 are shown in Figure 6. For the sample A1, which was electrolyzed at $0.90 \mathrm{~V}$, a change in color from transparent i.e., no color to dark brown is observed in a portion lower than the $\mathrm{Zn} / \mathrm{CaCl}_{2}$ interface ( 8 $\mathrm{mm}$ from the bottom of the $\mathrm{SiO}_{2}$ plate). Also, a decrease in plate thickness is clearly observed. In the case of the sample A2, which was electrolyzed at $0.60 \mathrm{~V}$, the entire area below the $\mathrm{Zn} / \mathrm{CaCl}_{2}$ interface changed to dark brown in color. In this case, the plate became thinner, showing that a larger amount of the $\mathrm{Si}-\mathrm{Zn}$ liquid alloy was produced. 
comparison with the two-phase interface of $\mathrm{Zn} / \mathrm{SiO}_{2}$ in liquid $\mathrm{Zn}$. This is explained by

higher solubility and faster diffusion of $\mathrm{O}^{2-}$ ions in molten $\mathrm{CaCl}_{2}$ compared with those

212 in liquid $\mathrm{Zn}$. As for the immersion sample B1, no dark brown part is observed,

213 indicating no progress of indirect reduction. Concerning the sample B2, which was

214 immersed after electrolysis at $0.60 \mathrm{~V}$, the color of the immersed portion changed to dark

215 brown. This is explained by the indirect reduction. The weight losses of the samples

216 were $0.03 \mathrm{~g}(\mathrm{~A} 1), 0.07 \mathrm{~g}(\mathrm{~A} 2), 0.00 \mathrm{~g}(\mathrm{~B} 1)$, and $0.03 \mathrm{~g}(\mathrm{~B} 2)$.

217 By comparing the samples A1 and B1, it can be inferred that only the direct

218 reduction of $\mathrm{SiO}_{2}$ (reaction [5]) occurs at $0.90 \mathrm{~V}$. On the other hand, the results for

219 sample A2 and B2 conclude that comparable amount of reduction proceeded in the

220 indirect reaction, i.e., reduction by liquid $\mathrm{Ca}-\mathrm{Zn}$ alloy (reaction [6]), in the electrolysis

at $0.60 \mathrm{~V}$ to the direct reduction.

(c) Electrolytic reduction of $\mathrm{SiO}_{2}$ particles

To prepare a sample for impurity analysis, potentiostatic electrolysis of $\mathrm{SiO}_{2}$

particles was conducted at $0.60 \mathrm{~V}$ for $50 \mathrm{~h}$. Figure 7 (a) shows a photograph of the 
228 The current efficiency $(\eta)$ is calculated by the following equations:

$$
\begin{aligned}
& \eta=\frac{W_{\text {act. }}}{W_{\text {theo. }}} \times 100 \\
& W_{\text {theo. }}=\frac{Q}{4 F} \times M_{\mathrm{Si}}
\end{aligned}
$$

229

232 purified by unidirectional solidification according to the process proposed in Figure 1.

where $Q$ is the quantity of electric charge during electrolysis, $F$ is Faraday's constant (96485 $\left.\mathrm{C} \mathrm{mol}^{-1}\right), M_{\mathrm{Si}}$ is the molar weight of $\mathrm{Si}\left(28.1 \mathrm{~g} \mathrm{~mol}^{-1}\right), W_{\text {act. }}$ is the actual weight of the Si recovered, and $W_{\text {theo. }}$ is the theoretical weight of Si by Faraday's law in reaction [5]. From the values of $W_{\text {act. }}=3.02 \mathrm{~g}$ and $Q=1.48 \times 10^{5} \mathrm{C}, \eta$ is calculated to be $28 \%$. One of the reasons for the low current efficiency is the loss during acid washing. Another is the formation of liquid $\mathrm{Ca}-\mathrm{Zn}$ alloy as a side reaction; a part of it contributes to the indirect reduction of $\mathrm{SiO}_{2}$ and the other remains as $\mathrm{Ca}-\mathrm{Zn}$ alloy.

Table 1 lists the impurity contents of the Si granules after the treatment of acid washing. It also lists the acceptable levels for $\mathrm{SOG}_{-\mathrm{Si}^{41}}{ }^{1}$, segregation coefficients ${ }^{7}$, and target levels for primary Si for directional solidification. For comparison, the impurity contents of the Si sample obtained by solid electrolytic reduction at $0.60 \mathrm{~V}$ for $5 \mathrm{~h}$ in molten $\mathrm{CaCl}_{2}$ are also shown ${ }^{42}$. The impurity levels of the metallic elements (Al, $\mathrm{Ca}, \mathrm{Fe}$, and $\mathrm{Ti}$ ) in the $\mathrm{Si}$ granules meet the target levels for the primary $\mathrm{Si}$ that is to be further 
244 noteworthy because the removal of $\mathrm{P}$ from elemental Si is known to be difficult. The

245 content of B is higher than the target level, and this needs to be improved in the future.

246 Overall, a comparison between the impurity concentrations in the Si products obtained

247 by electrolysis at a liquid $\mathrm{Zn}$ cathode and at a solid electrode indicates that higher purity

248 is achieved by the use of the liquid $\mathrm{Zn}$ electrode. The main reason for the higher purity

249 is the solidification refining during the precipitation of $\mathrm{Si}$ from the $\mathrm{Si}-\mathrm{Zn}$ alloy wherein

250 most impurities remain in the liquid $\mathrm{Zn}$ phase. It should be mentioned that the $\mathrm{Ca}$

251 concentration is lower than the target level for the primary Si in spite of the use of

252 indirect reduction by liquid $\mathrm{Ca}-\mathrm{Zn}$ at $0.60 \mathrm{~V}$. Calcium is also expected to be removed to

253 the $\mathrm{Zn}$ phase during precipitation. Although a relatively large amount of $\mathrm{Zn}$ (6055

254 ppmw) remained in the Si granules, this can be easily removed in the gas phase during

255 the refining process owing to its high vapor pressure.

\section{Conclusion}

The reaction mechanism of electrolytic reduction of $\mathrm{SiO}_{2}$ at a liquid $\mathrm{Zn}$ cathode

was investigated in molten $\mathrm{CaCl}_{2}$ at $1123 \mathrm{~K}$. Cyclic voltammetry suggested that 
262 reduction of $\mathrm{SiO}_{2}$ by liquid $\mathrm{Ca}-\mathrm{Zn}$ alloy was confirmed by electrolysis and immersion

263 experiments. The reduction at $0.60 \mathrm{~V}$ proceeded by a mixed reduction mechanism of

264 direct electrolytic reaction and indirect reduction by $\mathrm{Ca}-\mathrm{Zn}$ alloy. Impurity analysis

265 confirmed that the concentrations of the metal elements and $\mathrm{P}$ were lower than the target

266 levels for primary $\mathrm{Si}$. The indirect reduction of $\mathrm{SiO}_{2}$ by liquid $\mathrm{Ca}-\mathrm{Zn}$ does not increase

267 the $\mathrm{Ca}$ content of the $\mathrm{Si}$ product because it is removed to the $\mathrm{Zn}$ phase during 268 precipitation.

Acknowledgements

This study was partially supported by Core Research for Evolutionary Science

and Technology (CREST) from the Japan Science and Technology Agency (JST);

Grant-in-Aid for Scientific Research A, Grant Number 16H02410, from the Japan

Society for the Promotion of Science (JSPS); the Kato Foundation for Promotion of

Science; and The Joint Usage/Research Center for Zero Emission Energy Research

(ZE28A12), Institute of Advanced Energy, Kyoto University.

\section{References}

279

1. Photovoltaic Market 2017, RTS Corp. (2017). [in Japanese]

280

2. Industrial Rare Metal 2017, Arumu Publ. Co. (2017). 
3. H. Schweickert, K. Reusche and H. Gustsche, U.S. Patent 3011877, (1961).

4. H. Gutsche, U.S. Patent 3011877, (1962).

5. C. Bye and B. Ceccaroli, Sol. Energ. Mater. Sol. C., 130, 634 (2014).

6. G. Burns, J. Rabe and S. Yilmaz, PCT International Patent WO2005/061383, (2005).

7. F. A. Trumbore, Bell Syst. Tech. J., 39, 205 (1959).

8. X. Ma, T. Yoshikawa and K. Morita, Sep. Purif. Technol., 125, 264 (2014).

9. Y. Wang, X. Ma and K. Morita, Metall. Mater. Trans. B, 45, 334 (2014).

10. K. Tang, S. Andersson, E. Nordstrand and M. Tangstad, JOM, 64, 952 (2012).

11. K. Hanazawa, N. Yuge and Y. Kato, Mater. Trans., 45, 844 (2004).

12. D. W. Lyon, C. M. Olson and E. D. Lewis, J. Electrochem. Soc., 96, 359 (1949).

13. S. Yoshizawa, T. Hatano and S. Sakaguchi, Kogyo Kagaku Zasshi, 64, 1347 (1961). [in Japanese]

14. J. M. Blocher, Jr., M. F. Browning and D. A. Seifert, DOE/JPL Report 954339-81/21 (1981).

15. A. Sanjurjo, PCT International Patent WO1983/002443, (1983).

16. T. B. Massalski, H. Okamoto, P. R. Subramanian and L. Kacprzak, Binary Alloy Phase Diagrams, 2nd ed., ASM International, Metals Park, Ohio, USA (1990).

17. T. Nohira, K. Yasuda and Y. Ito, Nat. Mater., 2, 397 (2003).

18. K. Yasuda, T. Nohira, K. Amezawa, Y. H. Ogata and Y. Ito, J. Electrochem. Soc., 152, D69 (2005).

19. K. Yasuda, T. Nohira, R. Hagiwara and Y. H. Ogata, Electrochim. Acta, 53, 106 (2007).

20. T. Nohira, Yoyuen Oyobi Koon Kagaku, 54, 95 (2011). [in Japanese]

21. M. Bessho, Y. Fukunaka, H. Kusuda and T. Nishiyama, Energy Fuels, 23, 4160 (2009).

22. T. Homma, N. Matsuo, X. Ynag, K. Yasuda, Y. Fukunaka and T. Nohira, Electrochim. Acta, 179, 512 (2015).

23. X. Jin, P. Gao, D. Wang, X. Hu and G. Z. Chen, Angew. Chem. Int. Ed., 43, 733 (2004).

24. P. C. Pistorius and D. J. Fray, J. SAIMM, 106, 31 (2006).

25. S. Lee, J. Hur and C. Seo, J. Ind. Eng. Chem., 14, 651 (2008).

26. J. Yang, S. Lu, S. Kan, X. Zhang and J. Du, Chem. Commun., 3273 (2009).

27. E. Juzeliunas, A. Cox and D. J. Fray, Electrochem. Commun., 12, 1270 (2010).

28. W. Xiao, X. Jin, Y. Deng, D. Wang and G. Z. Chen, J. Electroanal. Chem., 639, 130 (2010). 
29. E. Ergül, İ. Karakaya and M. Erdoğan, J. Alloy. Compd., 509, 899 (2011).

30. S. Cho, F. F. Fan and A. J. Bard, Electrochim. Acta, 65, 57 (2012).

31. H. Nishihara, T. Suzuki, H. Itoi, B. An, S. Iwamura, R. Berenguer and T. Kyotani, Nanoscale, 6, 10574 (2014).

32. S. Fang, H. Wang, J. Yang, S. Lu, B. Yu, J. Wang and C. Zhao, Mater. Lett., 160, 1 (2015).

33. S. Fang, H. Wang, J. Yang, S. Lu, B. Yu, J. Wang and C. Zhao, Rare Metal, 89, 1 (2016).

34. S. Fang, H. Wang, J. Yang, S. Lu, B. Yu, J. Wang and C. Zhao, J. Phys. Chem. Solids, 89, 1 (2016).

35. T. Toba, K. Yasuda, T. Nohira, X. Yang, R. Hagiwara, K. Ichitsubo, K. Masuda and T. Homma, Electrochemistry, 81, 559 (2013).

36. T. Nohira, A. Ido, T. Shimao, X. Yang, K. Yasuda, R. Hagiwara and T. Homma, ECS Trans., 75, 17 (2016).

37. K. Yasuda, T. Shimao, R. Hagiwara, T. Homma and T. Nohira, J. Electrochem. Soc., 164, H5049 (2017).

38. R. W. Olensinski and G. J. Abbaschian, Bull. Alloy Phase Diagr., 5, 271 (1984).

39. K. Yasuda, T. Nohira and Y. Ito, J. Phys. Chem. Solids, 66, 443 (2005).

40. H. Kadowaki, Y. Katasho, K. Yasuda and T. Nohira, J. Electrochem. Soc., 165, D83 (2018).

41. N. Yuge, M. Abe, K. Hanazawa, H. Baba, N. Nakamura, Y. Kato, Y. Sakaguchi, S. Hiwasa and F. Aratani, Prog. Photovolt. Res. Appl., 9, 203 (2001).

42. X. Yang, K. Yasuda, T. Nohira, R. Hagiwara and T. Homma, Metall. Mater. Trans. E, 3, 145 (2016). 


\section{Table and Figure captions}

Table 1 Impurity contents of Si granules obtained after acid leaching, and target levels for primary $\mathrm{Si}$ of $\mathrm{SOG}-\mathrm{Si}$. The electrolytic reduction of $\mathrm{SiO}_{2}$ particles was conducted at $0.6 \mathrm{~V}$ for $50 \mathrm{~h}$ at a liquid $\mathrm{Zn}$ cathode in molten $\mathrm{CaCl}_{2}$ at $1123 \mathrm{~K}$.

Figure 1 Schematic drawing of SOG-Si production process using electrochemical reduction of $\mathrm{SiO}_{2}$ powder at a liquid $\mathrm{Si}-\mathrm{Zn}$ alloy cathode in molten $\mathrm{CaCl}_{2} .{ }^{36,37}$

Figure 2 Schematic illustration of the electrolysis cell for observation of $\mathrm{SiO}_{2}$ reduction behavior at liquid $\mathrm{Zn}$ cathode. (a) $\mathrm{Ag}^{+} / \mathrm{Ag}$ reference electrode, (b) $\mathrm{Ca}^{2+} / \mathrm{Ca}$ dynamic reference electrode on a Mo wire, (c) liquid $\mathrm{Zn}$ electrode with $\mathrm{Al}_{2} \mathrm{O}_{3} / \mathrm{SiO}_{2}$ tube, (d) graphite counter electrode, (e) $\mathrm{Al}_{2} \mathrm{O}_{3}$ crucible, (f) molten $\mathrm{CaCl}_{2}$, (g) small $\mathrm{Al}_{2} \mathrm{O}_{3}$ crucible, and (h) liquid $\mathrm{Zn}$.

Figure 3 Schematic illustrations of the liquid $\mathrm{Zn}$ electrode for (a) cyclic voltammetry and (b) electrolytic reduction of $\mathrm{SiO}_{2}$ plate.

Figure 4 Schematic illustration of the electrolysis cell for the electrolytic reduction of $\mathrm{SiO}_{2}$ particles. (a) $\mathrm{Ag}^{+} / \mathrm{Ag}$ reference electrode, (b) $\mathrm{Ca}^{2+} / \mathrm{Ca}$ dynamic reference electrode on a Mo wire, (c) W lead wire, (d) graphite counter electrode, (e) $\mathrm{Al}_{2} \mathrm{O}_{3}$ crucible, (f) molten $\mathrm{CaCl}_{2}$, (g) $\mathrm{SiO}_{2}$ particle, and (h) liquid $\mathrm{Zn}$.

Figure 5 Cyclic voltammograms for liquid $\mathrm{Zn}$ electrode with an $\mathrm{Al}_{2} \mathrm{O}_{3}$ tube or a $\mathrm{SiO}_{2}$ 
Figure 6 Optical images of the $\mathrm{SiO}_{2}$ plates after electrolysis at liquid $\mathrm{Zn}$ electrode or

Figure 7 (a) An optical image and (b) XRD pattern of the Si granules obtained after acid leaching of $\mathrm{Zn}$ ingots. The electrolytic reduction of $\mathrm{SiO}_{2}$ particles was 
372 Table 1. Impurity contents of Si granules obtained after acid leaching, and target levels 373 for primary $\mathrm{Si}$ of SOG-Si. The electrolytic reduction of $\mathrm{SiO}_{2}$ particles was conducted at $3740.6 \mathrm{~V}$ for $50 \mathrm{~h}$ at a liquid $\mathrm{Zn}$ cathode in molten $\mathrm{CaCl}_{2}$ at $1123 \mathrm{~K}$.

\begin{tabular}{|c|c|c|c|c|c|}
\hline $\begin{array}{l}\text { Impurity } \\
\text { element, } \\
\text { A }\end{array}$ & $\begin{array}{c}\text { Acceptable level } \\
\text { for SOG-Si' } \\
x_{\mathrm{A}(\mathrm{SOG}-\mathrm{Si})} / \mathrm{ppmw}\end{array}$ & $\begin{array}{c}\text { Segregation } \\
\text { coefficient }^{7}, \\
k_{\mathrm{A}}^{\circ}\end{array}$ & $\begin{array}{c}\text { Target level for } \\
\text { primary } \mathrm{Si}^{\mathrm{a}}, \\
x_{\mathrm{A}(\text { primary })} / \mathrm{ppmw}\end{array}$ & $\begin{array}{c}\text { Impurity content } \\
\text { of Si granules by } \\
\text { electrochemical } \\
\text { reduction at } \\
\text { liquid } \mathrm{Zn} \\
\text { cathode, } \\
x_{\mathrm{A}} / \text { ppmw }^{\mathrm{b}}\end{array}$ & $\begin{array}{c}\text { Impurity } \\
\text { content of } \mathrm{Si} \\
\text { by direct } \\
\text { electrochemica } \\
1 \text { reduction }{ }^{42}, \\
x_{\mathrm{A}} / \mathrm{ppmw}^{\mathrm{c}}\end{array}$ \\
\hline B & $0.1-0.3$ & 0.8 & $0.13-0.38$ & 1.5 & 2.6 \\
\hline $\mathrm{P}$ & $0.03-0.04$ & 0.35 & $0.086-0.4$ & $<0.2$ & 6.4 \\
\hline $\mathrm{Al}$ & $<0.1$ & $2 \times 10^{-3}$ & $<50$ & 8 & 600 \\
\hline $\mathrm{Ca}$ & $<0.2$ & $1.6 \times 10^{-3}$ & $<125$ & 85 & 5800 \\
\hline $\mathrm{Fe}$ & $<0.1$ & $8 \times 10^{-6}$ & $<12500$ & 110 & 30 \\
\hline $\mathrm{Ti}$ & $<10^{-3}$ & $9 \times 10^{-6}$ & $<100$ & 25 & 19 \\
\hline $\mathrm{Zn}$ & $-^{\mathrm{d}}$ & $-^{\mathrm{d}}$ & $-^{\mathrm{d}}$ & 6055 & 2.1 \\
\hline
\end{tabular}

377 c: Analyzed by glow discharge-mass spectrometry (GD-MS) 


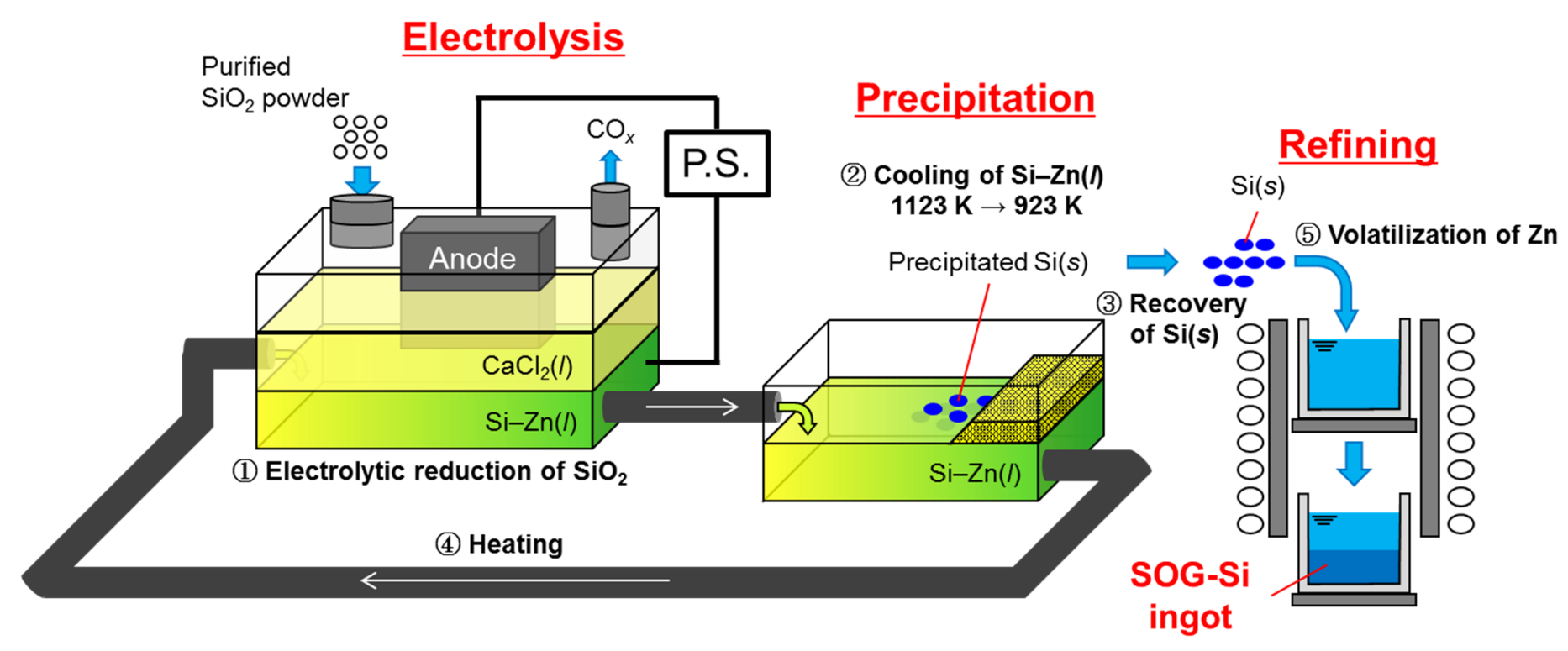

(6) Directional solidification

Figure 1. Schematic drawing of SOG-Si production process using electrochemical reduction of $\mathrm{SiO}_{2}$ powder at a liquid $\mathrm{Si}-\mathrm{Zn}$ alloy cathode in molten $\mathrm{CaCl}_{2}{ }^{38}$ 
(a) (b) (c) (d)

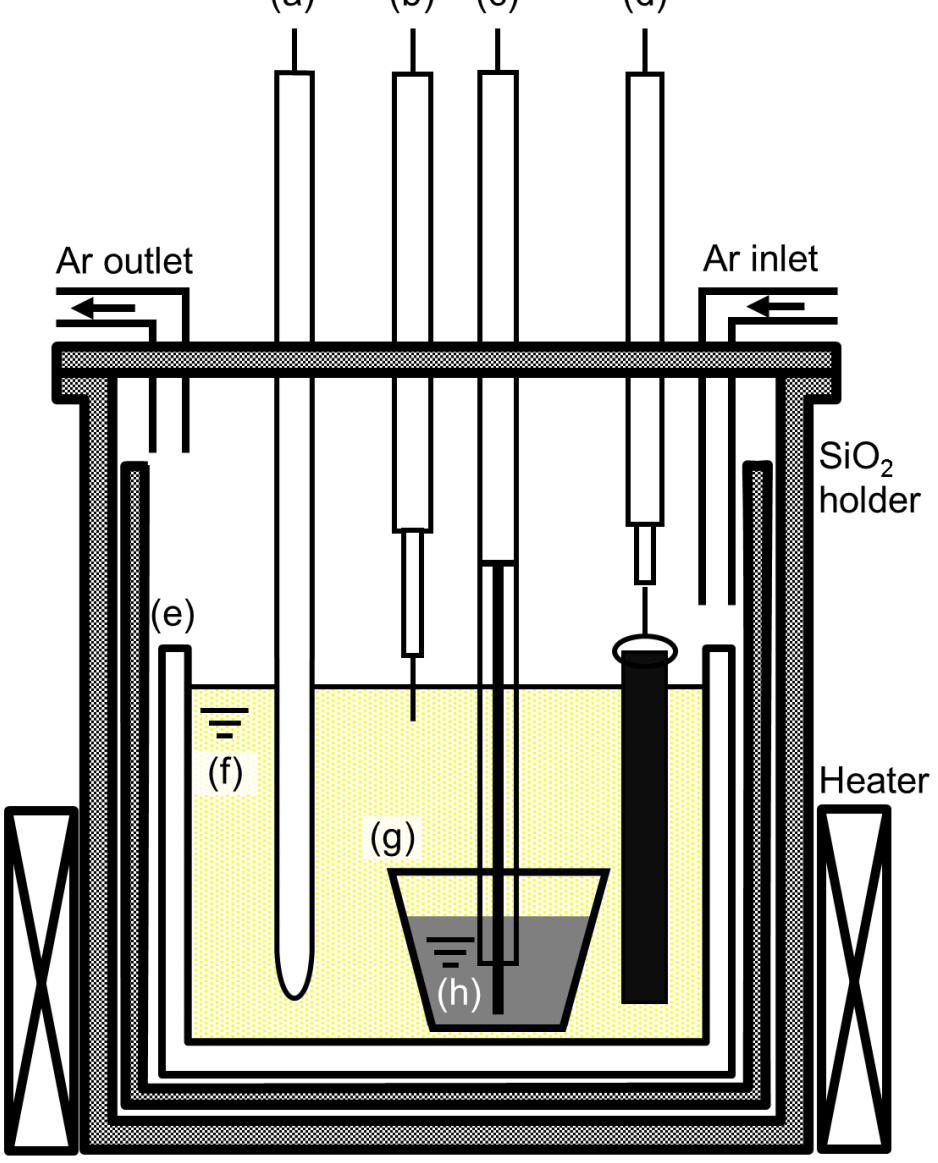

Figure 2. Schematic illustration of the electrolysis cell for observation of $\mathrm{SiO}_{2}$ reduction behavior at liquid $\mathrm{Zn}$ cathode. (a) $\mathrm{Ag}^{+} / \mathrm{Ag}$ reference electrode, (b) $\mathrm{Ca}^{2+} / \mathrm{Ca}$ dynamic reference electrode on a Mo wire, (c)liquid $\mathrm{Zn}$ electrode with $\mathrm{Al}_{2} \mathrm{O}_{3} / \mathrm{SiO}_{2}$ tube, (d) graphite counter electrode, (e) $\mathrm{Al}_{2} \mathrm{O}_{3}$ crucible, (f) molten $\mathrm{CaCl}_{2}$, (g) small $\mathrm{Al}_{2} \mathrm{O}_{3}$ crucible, and (h) liquid $\mathrm{Zn}$. 
(a)

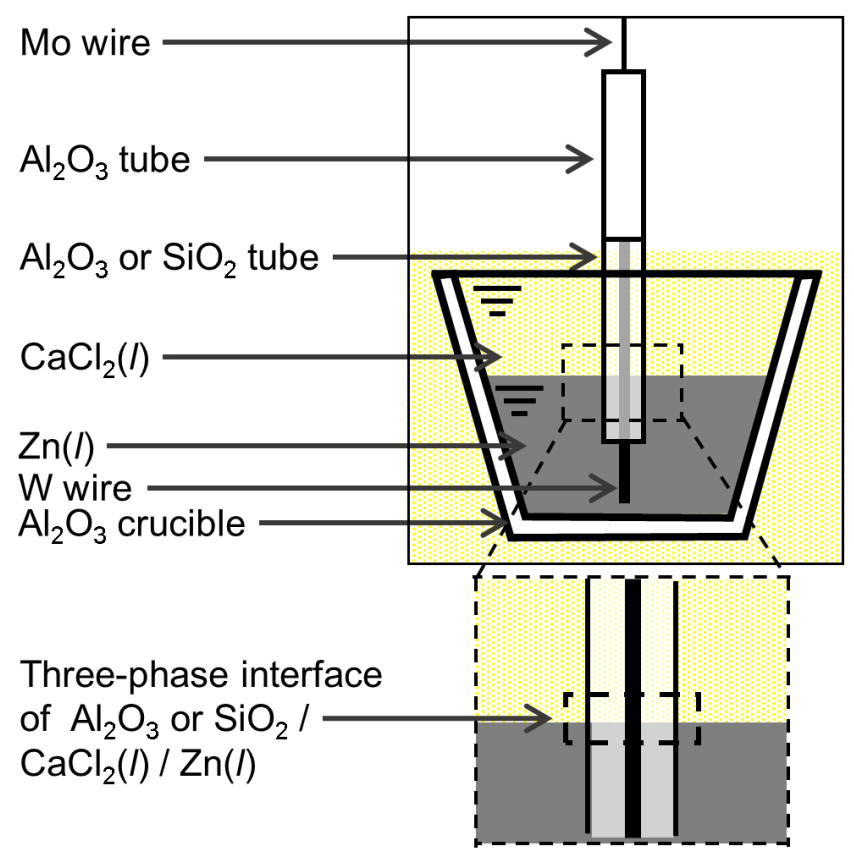

(b)

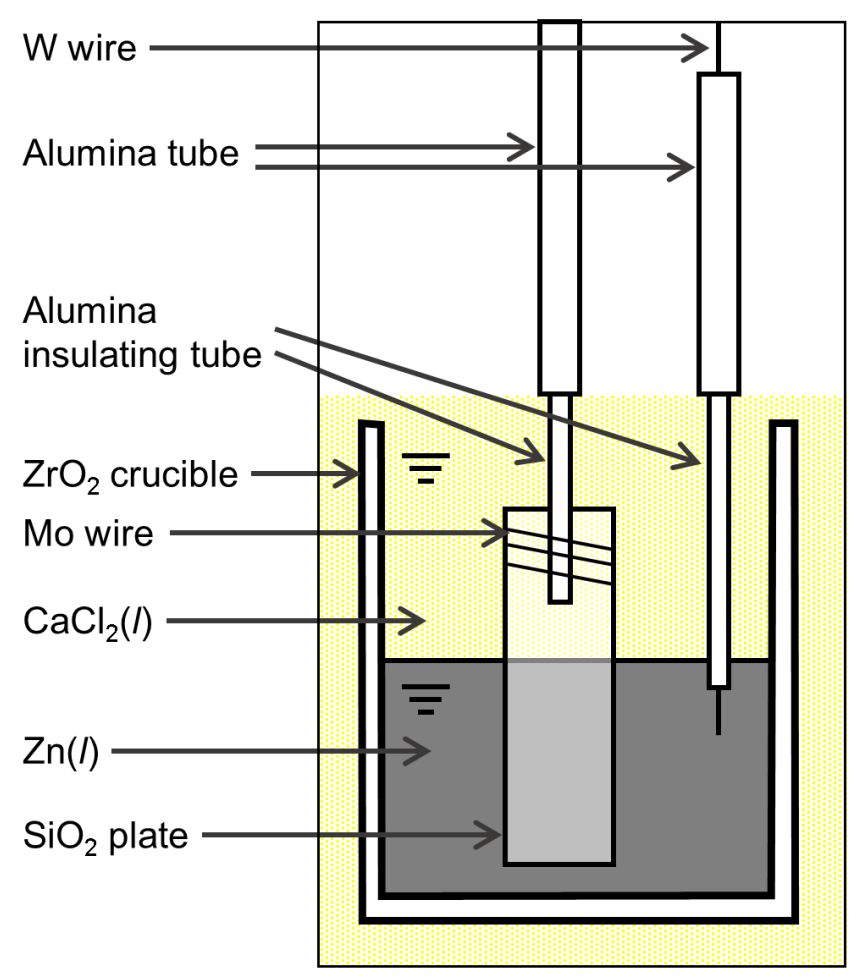

Figure 3. Schematic illustrations of the liquid $\mathrm{Zn}$ electrode for (a) cyclic voltammetry and (b) electrolytic reduction of $\mathrm{SiO}_{2}$ plate 


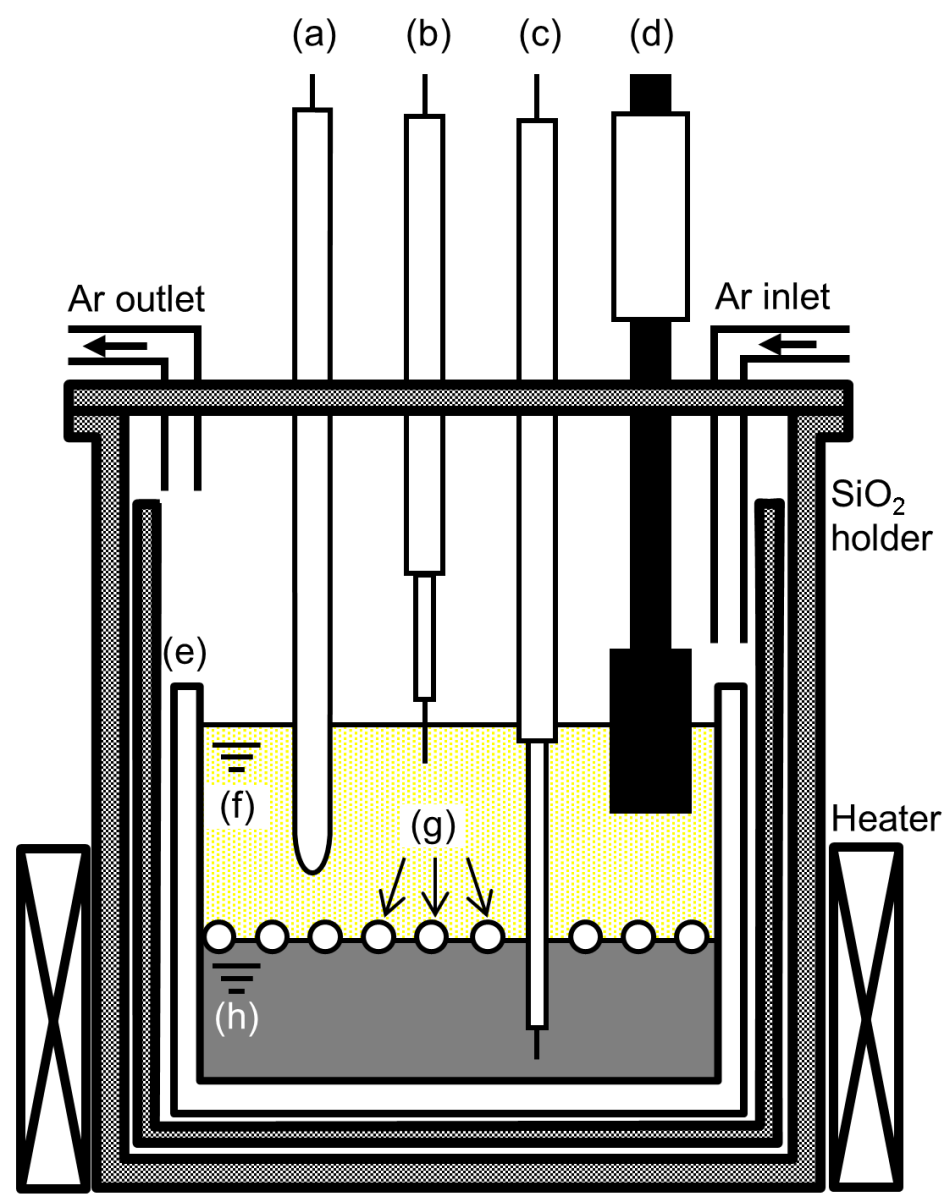

Figure 4. Schematic illustration of the electrolysis cell for the electrolytic reduction of $\mathrm{SiO}_{2}$ particles. (a) $\mathrm{Ag}^{+} / \mathrm{Ag}$ reference electrode, (b) $\mathrm{Ca}^{2+} / \mathrm{Ca}$ dynamic reference electrode on a Mo wire, (c) $\mathrm{W}$ lead wire, (d) graphite counter electrode, (e) $\mathrm{Al}_{2} \mathrm{O}_{3}$ crucible, (f) molten $\mathrm{CaCl}_{2}$, (g) $\mathrm{SiO}_{2}$ particle, and (h) liquid $\mathrm{Zn}$. 


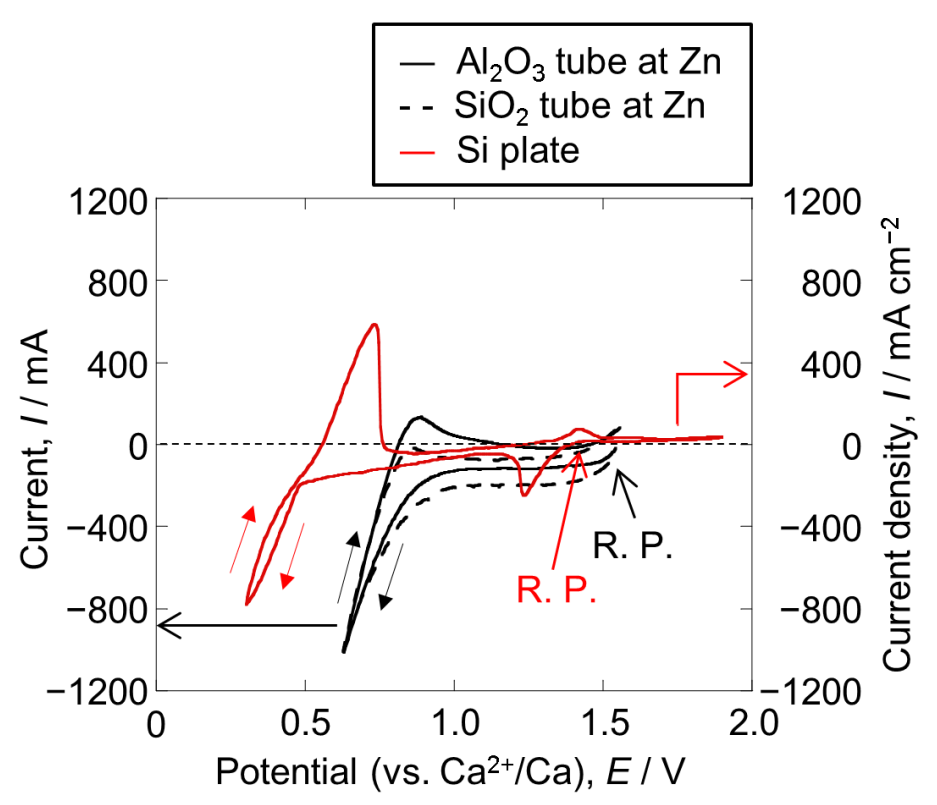

Figure 5. Cyclic voltammograms for liquid $\mathrm{Zn}$ electrode with an $\mathrm{Al}_{2} \mathrm{O}_{3}$ tube or a $\mathrm{SiO}_{2}$ tube (left axis) and for Si plate electrode (right axis) in molten $\mathrm{CaCl}_{2}$ at $1123 \mathrm{~K}$. Scan rate: $100 \mathrm{mV} \mathrm{s}^{-1}$. 
(a) A1

Electrolysis $(0.90 \mathrm{~V})$

(b) B1

Immersion after electrolysis $(0.90 \mathrm{~V})$

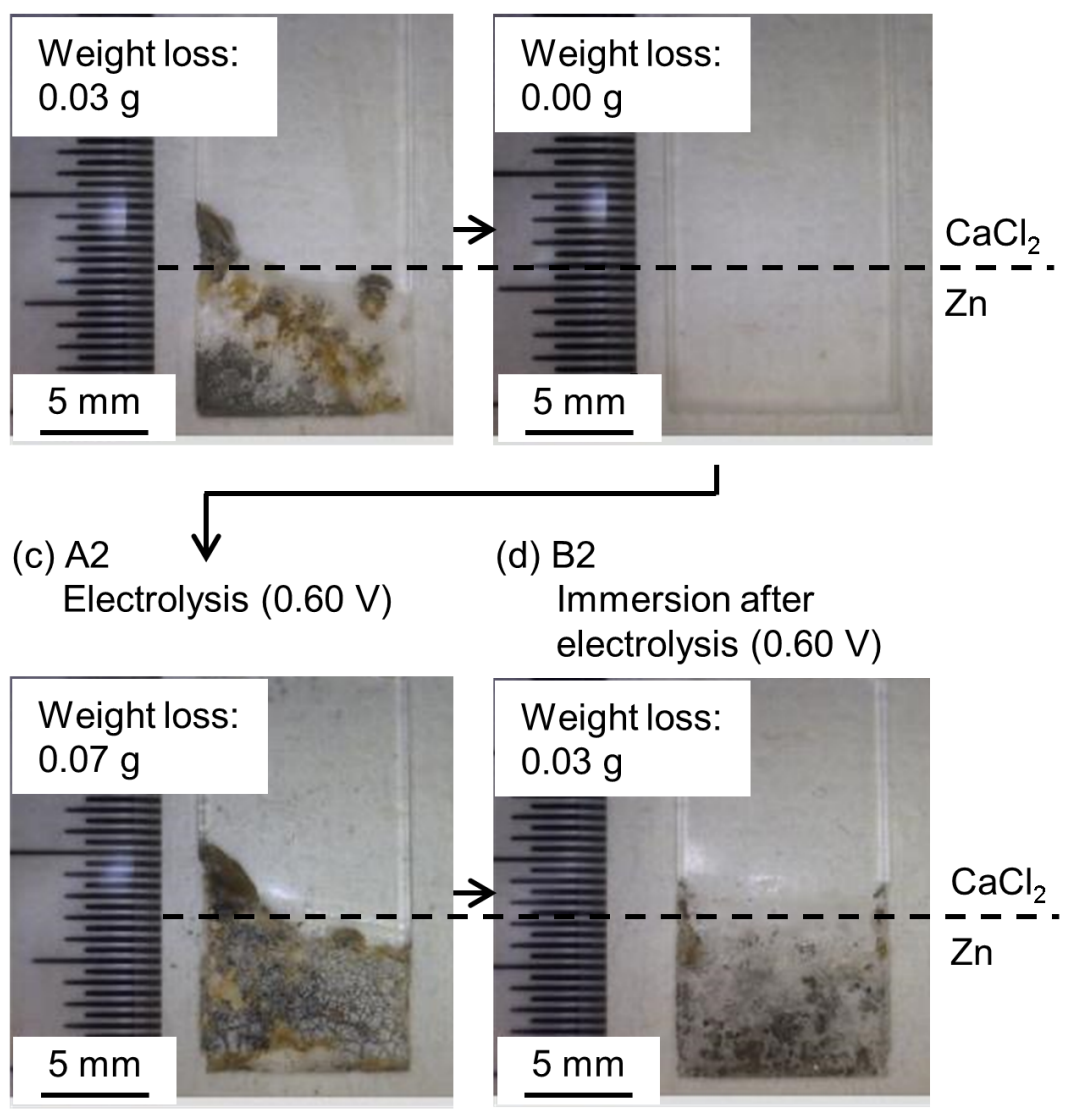

Figure 6. Optical images of the $\mathrm{SiO}_{2}$ plates after electrolysis at liquid $\mathrm{Zn}$ electrode or immersion into liquid $\mathrm{Zn}$ for 30 min in molten $\mathrm{CaCl}_{2}$ at $1123 \mathrm{~K}$. (a) potentiostatic electrolysis at $0.9 \mathrm{~V}$, (b) immersion after electrolysis (a), (c) potentiostatic electrolysis at $0.6 \mathrm{~V}$, and (d) immersion after electrolysis (c). 
(a)

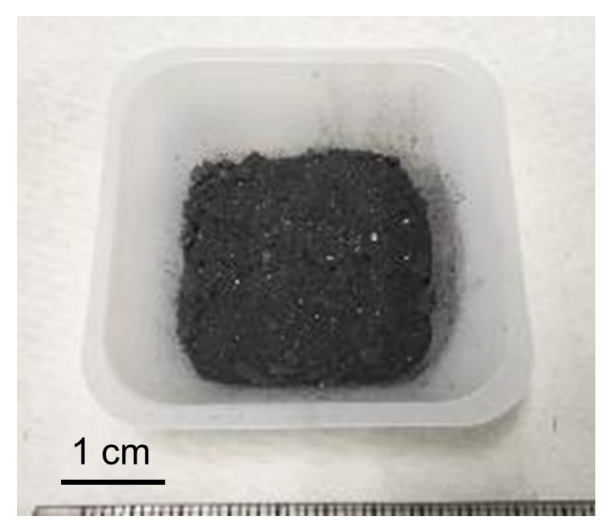

(b)

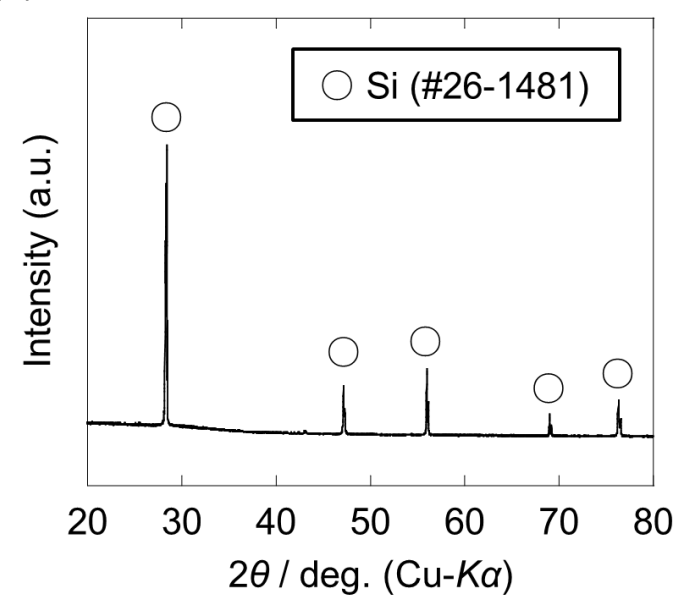

Figure 7. (a) An optical image and (b) XRD pattern of the $\mathrm{Si}$ granules obtained after acid leaching of $\mathrm{Zn}$ ingots. The electrolytic reduction of $\mathrm{SiO}_{2}$ particles was conducted at 0.6 $\mathrm{V}$ for $50 \mathrm{~h}$ at a liquid $\mathrm{Zn}$ cathode in molten $\mathrm{CaCl}_{2}$ at $1123 \mathrm{~K}$. 